\title{
THE EFFECTS OF FIRE ON VIRGIN NORTHERN MIXED GRASSLAND AT CUSTER NATIONAL MONUMENT
}

\author{
Jane H. Bock \\ E.P.O. Biology Department \\ University of Colorado \\ Boulder
}

The first field season of this work was completed on Labor Day, 1984. During this first summer, study plots were chosen on Custer Battlefield. Twenty of the plots were at scattered sites on the 1983 burn; five more plots, the controls, were placed on the unburned portion of the Monument. These plots all were located in relation to the NPS grid system which has been placed over the Monument grounds. From a coordinate permanent marker, twenty meters were measured to the north and to the west by means of a compass and metric tape. This accounted for three of the four corners of the $20 \times 20 \mathrm{~m}^{2}$ plots. The fourth corner was located subsequently. The coordinates for the plots on the burn are: N76-E24, N78-E19, N78-E18, N74-E28, N73-E28, N71-E28, N71-E26, N71-E25, N70-E22, N69-E20, N68-E21, N67-E23, N67-E23, N66-E25, N76-E18, N76-E20, N74-E22, N72-E21, N70-E19, N78-E27, and 15m west of soldier \#153's marker. The control plot coordinates are: N80-E19, N80-E18, N67-E27, N66-E26, and N67-E28. Five more $20 \times 20 \mathrm{~m}^{2}$ plots were selected on adjacent lands belonging to the Crow Indian Tribe where the 1983 fire had been. These plots contrasted with those on the Monument because the Crow people have kept cattle and horses on this land for several years, and they have continued this land use after the fire as well. The plots on the Indian lands are-south from N64-E24, south from N64-E28, east from N66-E30, east from N75-E30, and east from N73-E30.

On each plot we established vegetation transects. These were spaced $5 \mathrm{~m}$ apart. Sampling was done at $0.5 \mathrm{~m}$ intervals. At each sampling point we recorded 1) species present, 2) height of the plant, 3) reproductive condition. If no living plants were present at a sampling point, this was noted.

All woody species were censused on all study plots. All living woody plants were identified to species, their total height and canopy width recorded, and their phenological state and general health noted.

Each study plot was photographed from the coordinate stake which gave that plot its name. The camera was aimed diagonally across the study plot in each case.

Twenty 50 X $50 \mathrm{~cm}$ quadrats were located inside the borders of each plot at 4 $\mathrm{m}$ intervals. In each quadrat species present, number of individuals of each species, and a cover-sociability index for each species were recorded. Litter, bare ground, and dead grass also were given cover values.

On all plots except those on the Indian land, two $0.2 \mathrm{~m}$ samples of above-ground 
vegetation were clipped. These samples have been dried and weighed on the Boulder campus.

Pictures of the Battlefield and its environs are being collected. Sources include souvenir postcards and photos from the Battlefield archives. We are systematically trying to relocate and rephotograph the sites of the original photos. The oldest photos of the Battlefield, taken three years after the battle, show well developed sagebrush on Custer Hill. Books and manuscripts are being examined for comments on vegetation at the time of the battle. So far three relevant sources have been found.

A checklist of all flowering plant species to be found growing on the Monument is being prepared. From the first summer's work, this list approaches 100 species. No special efforts were made this first year to compile a complete list. In the second field season a special effort will be made to add species to this checklist. Dr. Tad Weaver and his colleagues at Montana State University are confirming the species identifications. Voucher specimens of the flora will be deposited at Montana State University because no herbarium is present at the Monument, and storage space is at a high premium there. 